\title{
Production of Trichoderma viride in Local Organic Substrates of the Ica Region, Peru
}

\section{Hanna Cáceres Yparraguirre ${ }^{*}$, Claudia Luciana Galliani-Pinillos}

Center for Agroindustrial Technological Innovation, Panamericana Sur Km 293.3 Salas Guadalupe Ica, CITEagroindustrial Ica, Peru

\begin{abstract}
Currently, in the face of attacks by pests and diseases in agricultural crops, new biological control strategies have been developed through the use of antagonistic fungi, of which the genus Trichoderma stands out. The objective of this research was to select the best organic substrate for the production of the species Trichoderma viride. Eight solid substrates were evaluated for the production of conidia of T. viride, with incubation at $20^{\circ} \mathrm{C}$ or $25^{\circ} \mathrm{C}$ and photoperiod $12 \mathrm{~h}$ light / $12 \mathrm{~h}$ dark for 13 days. The variables evaluated were density (number of conidia/g of substrate), percentage of germination, and purity of conidia. The best substrate, in which the highest number of conidia was obtained, was the dried lima bean shell at 5, 9 and 13 days of evaluation, under production at $20^{\circ} \mathrm{C}$. There was no statistically significant difference in the germination percentage and purity among the substrates evaluated. The best substrate regarding cost/benefit was the dried lima bean shell. It is concluded that this substrate is a new candidate for use in the production of T. viride by allowing a yield of $2 \times 10^{9}$ conidia/g at $20^{\circ} \mathrm{C}$ on day 5 and for being of lower economic value compared to whole rice.
\end{abstract}

Keywords: Biological control; Trichoderma viride; Biofungicide; Organic substrates; Zero residue agriculture

\section{INTRODUCTION}

The World Health Organization (WHO) reports 2-5 million cases annually of pesticide poisoning worldwide, of which 200,000 cases end in death; of these, $99 \%$ occur in rural areas of developing countries [1]. This alarming figure is due to the fact that most plant diseases are generally controlled with chemical fungicides, which are applied to the soil, seeds, foliage and fruit. The negative consequences on health, environmental pollution, residuality, and the development of resistance in phytopathogenic fungi have led to the search for replacement alternatives with the incorporation of biological agents [2].

A group of microorganisms that act as biocontrollers are fungi belonging to the genus Trichoderma. Within this we can highlight the species T. harzianum and T. viride. The latter is indicated as an organism with a high level of antagonistic activity towards a broad spectrum of phytopathogens [3] with the production of lipolytic, proteolytic, pectinolytic and cellulase enzymes [4,5], in addition to non-volatile antibiotics such as viridin with antifungal and antibacterial properties [6].

Trichoderma spp. are antagonistic fungi of phytopathogens that have shown favorable results in the biological control of dieback (trunk disease) in grapevine cultivars by Botryosphaeria spp. [7-10]. The use of native strains of Trichoderma spp. from the same area where pathogenic fungi occur had a greater biocontroller effect on them, compared to the use of foreign commercial strains [10,11].

In order to achieve the extensive use of mycopesticides (fungalbased biopesticides) within integrated pest management programs, beneficial fungal microorganisms must be susceptible to mass multiplication in an easy, effective, low-cost manner and economically profitable in order to guarantee large-scale availability [12]. Likewise, in the systems of myco-pesticide production, the use of regionally available materials that are residues of agroindustrial processes should be considered, which meets the requirements of green technologies and contributes to

*Correspondence to: Hanna Cáceres Yparraguirre, Agricultural Area of the Center for Agroindustrial Technological Innovation, Panamericana Sur Km 293.3 Salas Guadalupe Ica, CITEagroindustrial Ica, Peru, Tel: +51956185178; E-mail: hcaceres@citeagroindustrial.com

Received date: December 24, 2019; Accepted date: March 10, 2020; Published date: March 17, 2020

Citation: Yparraguirre HC (2020) Production of Trichoderma viride in local organic substrates of the Ica region - Peru. Plant Pathol Microbiol. 11:490. doi: 10.35248/2157-7471.20.11.490.

Copyright: ( 2020 Yparraguirre HC, et al. This is an open-access article dicstributed under the terms of the Creative Commons Attribution License, which permits unrestricted use, distribution, and reproduction in any medium, provided the original author and source are credited. 
the development of an environmentally and economically sustainable society [13]. Such is the case of lignocellulosic residues from the growing agroindustrial activity [14]. These residues are the most abundant of renewable biomass and substrates useful for the growth of filamentous fungi, inducing the production of cellulases, hemicellulases and enzymes for the degradation of lignocellulose by solid state fermentation [15].

Trichoderma spp. develop under different environmental and nutrient conditions. This facilitates its mass production in in vitro conditions on different low-cost substrates [16]. One of the most used substrates is the whole grain of rice, which has a relatively high cost [17]. Different studies have evaluated and optimized different substrates for the production of Trichoderma species, among them, the dry mass of corn fiber, sewage sludge, compost, sawdust, rice straw, cow dung, rice bran, vegetable waste, residues of fruit juices and rotten wheat [18]. Other organic substrates used for the development of this fungus were: tomato peel, garlic, cocoa, sesame, peanut, coffee, bean pod, corn grove, birdseed, soybean and corn stubble, reported by Michel-Aceves et al. [19].
The purpose of the present investigation was to evaluate eight organic substrates available locally in the Ica region for the production of $T$. viride and to select the best substrate, in which the greatest amount of conidia is obtained.

\section{MATERIALS AND METHODS}

\section{Place of study}

The research was carried out in the Laboratory of Agricultural Microbiology at the CITEagroindustrial-Ica, located in the district of Salas Guadalupe, Province and Department of Ica.

\section{Organic substrates}

The organic substrates evaluated were sawdust, yellow corn grain, oatmeal, birdseed, dried lima bean shell, wheat grain, grape marc and huaranga pod (Table 1).

Table 1: Organic substrates used for the production of Trichoderma viride.

\begin{tabular}{|c|c|c|c|c|}
\hline No & Substrate & Common name & Botanic description & $\begin{array}{l}\text { Particle } \\
\text { size }\end{array}$ \\
\hline 1 & Avena sativa $\mathrm{L}$. & oats & Oatmeal & - \\
\hline 2 & Triticum sativum $\mathrm{L}$. & wheat & Wheat grains & $6.00 \mathrm{~mm}$ \\
\hline 3 & Vitis vinifera & marc & Grape marc (solid remains of grapes, after pressing for juice) & $17.00 \mathrm{~mm}$ \\
\hline 4 & Prosopis pallida & huaranga & Fruit (or pod) of the tree & $15.00 \mathrm{~mm}$ \\
\hline 5 & Phaseolus lunatus & lima bean & Dried lima bean shell & $25.00 \mathrm{~mm}$ \\
\hline 6 & Zea mays & corn & Corn kernels & $2.5 \mathrm{~mm}$ \\
\hline 7 & Phalaris canariensis & birdseed & Birdseed & $5.0 \mathrm{~mm}$ \\
\hline 8 & $\begin{array}{l}\text { Cedrelinga catenaeformis, } \\
\text { Copaifera paupera, } \\
\text { Pinus cembra and } \\
\text { Cedrela odorata }\end{array}$ & $\begin{array}{l}\text { Sawdust originating from } \\
\text { the trees: tornillo, copaiba, } \\
\text { pine and cedro }\end{array}$ & $\begin{array}{l}\text { Waste or scrap of the wood cutting work of these four trees } \\
\text { collected in carpentry shops }\end{array}$ & - \\
\hline
\end{tabular}

\section{Obtaining the antagonist fungus isolate}

The strain CCBLA103 of Trichoderma viride used in this study was obtained from the National Biological Control Program of the National Agricultural Health Service of Peru (SENASA), in the framework of the UVASANA project in 2017-2018 subsidized by the National Agrarian Innovation Program (PNIA). The methodology used was adapted from a manual on the production, use of antagonistic fungi and quality control from SENASA [20].

The isolation consisted of directly adding $10 \mathrm{ml}$ (stock solution) of the product provided by SENASA. It was subsequently poured into a glass tube with a screw cap and sealed with
Parafilm. Finally, it was kept refrigerated within the temperature range $0^{\circ} \mathrm{C}$ to $10^{\circ} \mathrm{C}$.

In order to activate the microorganism, serial dilutions were made of the stock solution, so that it was subsequently plated on plates with potato dextrose agar (PDA) incubated at a temperature of $25^{\circ} \mathrm{C}$ for seven days. The cultures were then washed with a $0.1 \%$ Tween 80 solution in order to help detach the conidia. Subsequently, this concentration was counted in the Neubauer chamber, resulting in $1 \times 10^{5}$ colony forming units $(\mathrm{CFU}) / \mathrm{mL}$. Finally, from that concentrate, it was directly inoculated in a potato-dextrose broth $(400 \mathrm{~mL})$ as pre-inoculum, leaving it under stirring at $230 \mathrm{rpm}$ for 3 days. 


\section{In vitro preparation of substrates}

First, in order to remove the greatest amount of extraneous particles from the substrate, each of the substrates was washed for 2 min separately under running tap water and allowed to drain for $10 \mathrm{~min}$ on the same strainer where it was washed. Then $150 \mathrm{~g}$ (wet weight) of the substrate were placed in high density polyethylene bags and $15 \mathrm{~mL}$ of distilled water. The bags were sealed with metal staples. All bags were sterilized in an automatic autoclave at $121^{\circ} \mathrm{C}, 15$ psi pressure for $15 \mathrm{~min}$.

\section{Inoculation of substrates with $T$. viride}

Sterile syringes were used with which $15 \mathrm{~mL}$ of the fungus suspension was inoculated, making sure to spread it over the entire substrate. Inoculations were performed for each substrate, incubating four repetitions at $20^{\circ} \mathrm{C}$ and four repetitions at $25^{\circ} \mathrm{C}$ for 13 days, with exposure to white light ( $12 \mathrm{~h}$ light: $12 \mathrm{~h}$ dark) in the climatic chamber. The bags were manually shaken daily in order to spread the conidia evenly on the substrate.

\section{Conidia counting}

At 5, 9 and 13 days of incubation, conidia counts per gram of substrate were performed. One gram of each of the substrates was taken in duplicate and transferred to test tubes containing $0.1 \%$ (v/v) Tween 80 sterile solution. The samples were homogenized on a vibratory shaker (vortex) for 1 min to detach the conidia, then serial dilutions were made and the counting was carried out using the Neubauer chamber. With the micropipette, a volume of $0.1 \mathrm{~mL}$ of the last dilution $\left(10^{-2}\right)$ was taken and the chamber filled by capillarity; then it was taken under a microscope, where the conidia were counted in the central quadrant and in the quadrant of the four corners of the chamber.

\section{Germination percentage and purity of conidia}

The germination of the conidia, parameter indicator of viability of the fungus in the substrates [21], was determined from the last dilution $\left(10^{-2}\right)$, which was vortexed for one minute and 0.1 $\mathrm{mL}$ of the aliquot was deposited in Petri dishes containing water agar culture medium, then incubated at $20^{\circ} \mathrm{C}$ or $25^{\circ} \mathrm{C}$ in the dark for 16 hours.

For each substrate a random sample (of the four repetitions) was taken, this procedure was performed three times for each random repetition of each treatment. The germinated and nongerminated conidia were determined [22] counting at least 200 conidia for each sample by light microscopy. It was taken into account that the germination tube is 2 times larger than the diameter of the conidia [23]. Finally, the data was recorded, taking the average of the 3 readings. The percentage of germinated and non-germinated conidia was determined by the following formula:

$$
\begin{aligned}
& \% \text { Germination }=\frac{a}{a+b} \times 100 \\
& a=\text { number of germinated conidia } \\
& b=\text { number of non-germinated conidia }
\end{aligned}
$$

With respect to purity, the tubes of the last dilution of the previously used sample were used, vortexed for 1 minute, and then $0.2 \mathrm{~mL}$ of the last dilution was inoculated on the surface in 3 Petri dishes with PDA. It was allowed to incubate for 5 days at a temperature of $25 \pm 2^{\circ} \mathrm{C}$. Finally, the plates were evaluated and the average number of CFU of the contaminants (environmental fungi) and the number of CFU of the evaluated fungus were calculated. It was multiplied by the inverse of the dilution and the volume used [24].

The data obtained were applied to the following formula:

$\%$ Purity $=\frac{\mathrm{CFU}_{\mathrm{ef}}}{\mathrm{CFU}_{\mathrm{t}}} \times 100$

$\mathrm{CFU}_{\mathrm{ef}}=$ Colony Forming Units of the evaluated fungus

$\mathrm{CFU}_{\mathrm{t}}=$ Total Colony Forming Units

\section{Statistical analysis}

The comparison of the conidia count, germination percentage and conidial purity data among the substrates evaluated was performed using an analysis of variance (ANOVA) and Tukey test with a significance level of 0.05 using the statistical software InfoStat version 2018.

\section{RESULTS AND DISCUSSION}

\section{Evaluation of different substrates for the production of conidia produced by Trichoderma viride}

Of the substrates evaluated at $20^{\circ} \mathrm{C}$ (Table 2), a greater growth of the fungus was evident in the dried lima bean shell, as well as a rapid colonization of the substrate in the first five days after inoculation, achieving $2 \times 10^{9}$ conidia/g. This was followed by birdseed with $1 \times 10^{9}$ conidia/g. On the other hand, those with low sporulation levels corresponded to sawdust $\left(1 \times 10^{6}\right.$ conidia/g), wheat grain $\left(3 \times 10^{7}\right.$ conidia/g) and corn grains $(3 \times$ $10^{7}$ conidia/g). In some substrates, as thirteen days of incubation with $T$. viride passed, the concentration of conidia increased to $5 \times 10^{8}$ conidia/g (corn grains), $7 \times 10^{8}$ conidia/g (oatmeal and grape marc) and $2 \times 10^{8}$ conidia/g (huaranga).

Of the substrates evaluated at $25^{\circ} \mathrm{C}$ (Table 3), the dried lima bean shell and huaranga proved to be the best substrates presenting $4 \times 10^{9}$ conidia/g and $1 \times 10^{9}$ conidia/g after thirteen days of incubation, respectively. They were followed by the corn grain $\left(9 \times 10^{8}\right.$ conidia/g), oatmeal $\left(5 \times 10^{8}\right.$ conidia/g), birdseed $\left(5 \times 10^{8}\right.$ conidia/g) and grape marc $\left(4 \times 10^{8}\right.$ conidia/g). On the other hand, after five days of inoculation, the sawdust and wheat grain substrates presented $1 \times 10^{8}$ conidia/g; however, at nine and thirteen days, the concentration of conidia decreased significantly to $1 \times 10^{7}$ and $1 \times 10^{6}$ conidia/g, respectively, in these substrates.

We can conclude that the optimal incubation temperature for $T$. viride was $20^{\circ} \mathrm{C}$, since at that temperature high conidia counts were obtained. 


\section{Germination percentage and purity}

Taking as reference that the optimum temperature for the development of Trichoderma was $20^{\circ} \mathrm{C}$, the germination percentage of $T$. viride was $\geq 80 \%$ for the eight substrates evaluated (Table 4), highlighting that the substrates with the highest sporulation, such as the dried lima bean shell and birdseed, also have high germination rates. In contrast, wheat grain and sawdust presented $82 \%$ and $80 \%$ germination rate, respectively. It is important to mention that Trichoderma spp. degrade very complex carbon polymers such as starch, pectin and cellulose, among others, thanks to the complex of hydrolytic enzymes they produce [25]. If very rigid substrates such as sawdust are used, the growth of the fungus is retarded.

On the other hand, all substrates yielded conidia of $T$. viride with a purity of $100 \%$, which indicates that they are accepted by the quality standards and represent a better option for the production of this fungus.

Finally, in relation to its cost, the most economical substrate that presented a good conidia count was the dried lima bean shell.

Table 2: Conidia number of $T$. viride in the substrates evaluated at $20^{\circ} \mathrm{C}$.

\begin{tabular}{|c|c|c|c|c|c|c|}
\hline Substrate & 5 days & & 9 days & & 13 days & \\
\hline $\begin{array}{l}\text { Sawdust of tornillo, } \\
\text { copaiba, pine and } \\
\text { cedro }\end{array}$ & $\begin{array}{l}1.00 \mathrm{E} \\
+06\end{array}$ & $\mathrm{a}$ & $\begin{array}{l}3.00 \mathrm{E} \\
+06\end{array}$ & $\mathrm{a}$ & $\begin{array}{l}4.00 \mathrm{E} \\
+07\end{array}$ & $\mathrm{a}$ \\
\hline Yellow corn kernels & $\begin{array}{l}3.00 \mathrm{E} \\
+07\end{array}$ & $\mathrm{a}$ & $\begin{array}{l}5.00 \mathrm{E} \\
+07\end{array}$ & $\mathrm{a}$ & $\begin{array}{l}5.00 \mathrm{E} \\
+08\end{array}$ & a \\
\hline Oatmeal & $\begin{array}{l}1.00 \mathrm{E} \\
+08\end{array}$ & a & $\begin{array}{l}2.00 \mathrm{E} \\
+08\end{array}$ & $\mathrm{a}$ & $\begin{array}{l}7.00 \mathrm{E} \\
+08\end{array}$ & $\mathrm{a}$ \\
\hline Birdseed & $\begin{array}{l}1.00 \mathrm{E} \\
+09\end{array}$ & $\mathrm{ab}$ & $\begin{array}{l}3.00 \mathrm{E} \\
+09\end{array}$ & $\mathrm{~b}$ & $\begin{array}{l}3.00 \mathrm{E} \\
+09\end{array}$ & $\mathrm{~b}$ \\
\hline $\begin{array}{l}\text { Dried lima bean } \\
\text { shell }\end{array}$ & $\begin{array}{l}2.00 \mathrm{E} \\
+09\end{array}$ & $\mathrm{~b}$ & $\begin{array}{l}2.00 \mathrm{E} \\
+09\end{array}$ & $\mathrm{~b}$ & $\begin{array}{l}4.00 \mathrm{E} \\
+09\end{array}$ & c \\
\hline Wheat grains & $\begin{array}{l}3.03 \mathrm{E} \\
+07\end{array}$ & $\mathrm{a}$ & $\begin{array}{l}1.00 \mathrm{E} \\
+07\end{array}$ & $\mathrm{a}$ & $\begin{array}{l}1.00 \mathrm{E} \\
+06\end{array}$ & a \\
\hline Grape marc & $\begin{array}{l}4.00 \mathrm{E} \\
+08\end{array}$ & $\mathrm{a}$ & $\begin{array}{l}2.21 \mathrm{E} \\
+08\end{array}$ & $\mathrm{a}$ & $\begin{array}{l}7.00 \mathrm{E} \\
+08\end{array}$ & $\mathrm{a}$ \\
\hline Huaranga & $\begin{array}{l}1.00 \mathrm{E} \\
+08\end{array}$ & $\mathrm{a}$ & $\begin{array}{l}1.00 \mathrm{E} \\
+08\end{array}$ & $\mathrm{a}$ & $\begin{array}{l}2.00 \mathrm{E} \\
+08\end{array}$ & a \\
\hline
\end{tabular}

Means per column followed with the same letter are not significantly different ( $p>0.05$ ) according to the test of Tukey

The purpose of this research was to determine a support medium that allows greater sporulation of $\mathrm{T}$. viride in a short time. For this, it must be borne in mind that the choice of substrates will depend on their cost and the nutritional requirements of the strain [26]. In general, the whole grain of rice is used, but it has a relatively high cost compared to several agroindustrial residues [17]. In the present study, other substrates have been evaluated: sawdust, yellow corn grain, oatmeal, birdseed, dried lima bean shell, wheat grain, grape marc and huaranga pod.

Table 3: Conidia number of T. viride in the substrates evaluated at $25^{\circ} \mathrm{C}$.

\begin{tabular}{|c|c|c|c|c|c|c|}
\hline Substrate & 5 days & & 9 days & & 13 days & \\
\hline $\begin{array}{l}\text { Sawdust of tornillo, } \\
\text { copaiba, pine and } \\
\text { cedro }\end{array}$ & $\begin{array}{l}1.00 \mathrm{E} \\
+08\end{array}$ & $\mathrm{a}$ & $\begin{array}{l}1.00 \mathrm{E} \\
+07\end{array}$ & $\mathrm{a}$ & $\begin{array}{l}1.00 \mathrm{E} \\
+07\end{array}$ & a \\
\hline Yellow corn kernels & $\begin{array}{l}4.00 \mathrm{E} \\
+08\end{array}$ & $\mathrm{~b}$ & $\begin{array}{l}8.00 \mathrm{E} \\
+08\end{array}$ & $\mathrm{ab}$ & $\begin{array}{l}8.88 \mathrm{E} \\
+08\end{array}$ & a \\
\hline Oatmeal & $\begin{array}{l}1.08 \mathrm{E} \\
+08\end{array}$ & $\mathrm{a}$ & $\begin{array}{l}5.00 \mathrm{E} \\
+08\end{array}$ & $\mathrm{ab}$ & $\begin{array}{l}5.01 \mathrm{E} \\
+08\end{array}$ & a \\
\hline Birdseed & $\begin{array}{l}1.04 \mathrm{E} \\
+08\end{array}$ & a & $\begin{array}{l}2.00 \mathrm{E} \\
+08\end{array}$ & $\mathrm{ab}$ & $\begin{array}{l}5.01 \mathrm{E} \\
+08\end{array}$ & a \\
\hline $\begin{array}{l}\text { Dried lima bean } \\
\text { shell }\end{array}$ & $\begin{array}{l}4.00 \mathrm{E} \\
+08\end{array}$ & $\mathrm{~b}$ & $\begin{array}{l}2.00 \mathrm{E} \\
+09\end{array}$ & c & $\begin{array}{l}4.00 \mathrm{E} \\
+09\end{array}$ & $\mathrm{~b}$ \\
\hline Wheat grains & $\begin{array}{l}1.00 \mathrm{E} \\
+08\end{array}$ & $\mathrm{a}$ & $\begin{array}{l}2.00 E \\
+06\end{array}$ & $\mathrm{a}$ & $\begin{array}{l}1.00 \mathrm{E} \\
+06\end{array}$ & a \\
\hline Grape marc & $\begin{array}{l}1.00 \mathrm{E} \\
+08\end{array}$ & $\mathrm{a}$ & $\begin{array}{l}1.00 \mathrm{E} \\
+08\end{array}$ & $\mathrm{ab}$ & $\begin{array}{l}4.00 E \\
+08\end{array}$ & a \\
\hline Huaranga & $\begin{array}{l}2.00 \mathrm{E} \\
+08\end{array}$ & $\mathrm{ab}$ & $\begin{array}{l}1.00 \mathrm{E} \\
+09\end{array}$ & $\mathrm{~b}$ & $\begin{array}{l}1.00 \mathrm{E} \\
+09\end{array}$ & a \\
\hline
\end{tabular}

Means per column followed with the same letter are not significantly different $(\mathrm{p}>0.05)$ according to the test of Tukey

Table 4: Germination percentage and purity of conidia, and cost of each substrate.

\begin{tabular}{lllll}
\hline Substrate & $\begin{array}{l}\text { Germinatio } \\
\mathbf{n}(\%)\end{array}$ & $\begin{array}{l}\text { Purity } \\
(\%)\end{array}$ & $\begin{array}{l}\text { Cost } \\
(\mathrm{S} / \mathrm{)} / \mathbf{k g}\end{array}$ \\
\hline $\begin{array}{l}\text { Sawdust of tornillo, } \\
\text { copaiba, pine and cedro }\end{array}$ & 80,0 & a & 100 & 3,00 \\
\hline Yellow corn kernels & 89,5 & b & 100 & 3,50 \\
\hline Oatmeal & 91,0 & b & 100 & 5,00 \\
\hline Birdseed & 89,5 & b & 100 & 5,00 \\
\hline Dried lima bean shell & 90,0 & b & 100 & 0,30 \\
\hline Wheat grains & 82,0 & a & 100 & 4,50 \\
\hline Grape marc & 89,5 & b & 100 & 0,10 \\
\hline Huaranga & 90,5 & b & 100 & 0,50 \\
\hline
\end{tabular}


Means per column followed with the same letter are not significantly different ( $p>0.05$ ) according to the test of Tukey

The results obtained show the dried lima bean shell as an alternative to the rice substrate used for the production of Trichoderma. Its nutritional composition is characterized by $12.88 \%$ hemicellulose, $4.05 \%$ lignin, and a carbon-to-nitrogen (C:N) ratio of 11:46 [27]. This $\mathrm{C}: \mathrm{N}$ ratio is one of the control parameters for fungal development, since microorganisms use nitrogen as an energy source and also to build their own materials [28]. This is evident in Trichoderma, which is capable of degrading very complex substrates such as starch, pectin and cellulose, among others, and use them for growth thanks to the large enzyme complex it possesses (amylases, pectinases, cellulases and chitinases, among others). Likewise, it assimilates as a source of nitrogen compounds such as amino acids, urea, nitrites, ammonia and ammonium sulfate [25]. According to Tovar [29], Trichoderma has the ability to use very efficiently the nutrients found in the environment in limited quantities.

In the research conducted by Kobori et al. [30], the authors reported obtaining a high concentration of conidia and microsclerotia of T. harzianum Rifai T-22 (9.55 $\times 10^{8}$ conidia/mL and $22.59 \times 10^{4} \mathrm{MS} / \mathrm{mL}$, respectively) at 7 days, when the culture medium was liquid (containing molasses and cottonseed meal) and with a C:N ratio of 50:1. In turn, Villamizar et al. [31] obtained microsclerotia of three Beauveria species $(6.18 \times 103$ $\mathrm{MS} / \mathrm{mL}$ ) in solid medium with a $\mathrm{C}: \mathrm{N}$ ratio of $5: 1$ or $4: 1$, and the carbon source was corn liquor. The high concentration of carbon and nitrogen of the nutritional sources present in the substrate or culture medium allows the microorganism to carry out the synthesis of compounds necessary for its development.

Michel et al. [32] carried out a massive reproduction of the fungus Trichoderma harzianum on substrates, obtaining $3 \times 10^{4}$ conidia/mL in the rice grain, $2 \times 10^{4}$ conidia $/ \mathrm{mL}$ in the birdseed, and $0.3 \times 10^{4}$ conidia/ $\mathrm{mL}$ in broken corn. These data differ from our investigation by reporting here a greater number of conidia of T. viride in birdseed $\left(1 \times 10^{9} \mathrm{CFU} / \mathrm{g}\right)$ and corn $(3 \times$ $\left.10^{7} \mathrm{CFU} / \mathrm{g}\right)$ at 5 days of incubation at $20^{\circ} \mathrm{C}$.

On the other hand, the lowest concentration of conidia was reported here for the sawdust substrate (residue or scrap of wood cutting work in carpentry shops) with $1 \times 10^{6}$ conidia/g at $20^{\circ} \mathrm{C}$. Sawdust has a C:N ratio of 500:1 [33]. It is important to note that the C:N ratio must be 10:1 for a culture medium. Under conditions similar to soil, compost or a similar matrix, it is recommended to look for 15:1 - 40:1 ratios [34,35].

Several authors [36] recommend the solid fermentation process to obtain fungal biomass. Solid fermentation involves interactions of microbial biomass with a wetted solid substrate. In it, the microorganism can grow between the fragments of the substrate, for example, within the matrix or on the surface of the substrate. Microbial biomass within the matrix consumes the substrate and secretes metabolites and enzymes [37].

Likewise, the particle size of the substrates that was used in this study was adequate for a good production of conidia. The support media inoculated with $T$. viride were exposed to temperatures of $20^{\circ} \mathrm{C}$ and $25^{\circ} \mathrm{C}$, with exposure to light, obtaining values greater than $80 \%$ germination and a purity of $100 \%$. It is known that moisture and particle size in the material play a fundamental role, as well as other parameters such as light and temperature. The species of the genus Trichoderma are aerobic fungi with the ability to tolerate a wide range of temperatures [38], and they behave better with daylight conditions and temperatures close to $25^{\circ} \mathrm{C}$ [39]. In other words, the alternation of light and its spectrum influence sporulation, pigmentation and secondary metabolite production [40-42]. Unlike what was reported by Fonseca [39], in the present study we found that the optimal temperature for the development of T. viride was $20^{\circ} \mathrm{C}$.

It is known that to use $T$. viride both in the greenhouse and in the field, concentrations from $4.5 \times 10^{9}$ conidia/g are necessary, according to the recommendations of the National Biological Control Program of the National Agricultural Health Service of Peru [43]. Therefore, in the present investigation ideal concentrations of conidia of this fungus were obtained, using as substrate dried lima bean shell, to be used in field applications [44].

\section{CONCLUSION}

In this study, different organic substrates and two incubation temperatures were evaluated, in order to obtain a higher production of conidia of T. viride. The optimum temperature for the development of this antagonistic fungus for 13 days was $20^{\circ} \mathrm{C}$. The production of conidia was higher in the dried lima bean shell substrate with a concentration of $2 \times 10^{9}$ conidia/g at 5 days of incubation at $20^{\circ} \mathrm{C}$. This yield almost equals that of the conventional substrate $\left(4.5 \times 10^{9}\right.$ conidia/g in whole rice $)$ reported by SENASA. The second substrate with a high concentration of conidia was based on birdseed $\left(1 \times 10^{9}\right.$ conidia/g at 5 days of incubation at $20^{\circ} \mathrm{C}$ ). At $25^{\circ} \mathrm{C}$, the dried lima bean shell and the huaranga pod presented $2 \times 10^{9}$ conidia/g and $1 \times 10^{9}$ conidia/g at 9 days, respectively.

The germination percentage of conidia of $T$. viride in the different substrates showed levels higher than $80 \%$. In all cases $100 \%$ purity was obtained. This indicates that the different substrates evaluated meet the quality standards for the formulation of biopreparations of T. viride and represent a good alternative for the production of this fungus.

Finally, the substrate that presented the highest production of conidia in a short time and in turn one of the lowest priced was the dried lima bean shell. This is a residue that is obtained in the harvest of lima bean, an important crop for local and national consumption, and that has a designation of origin since 2007.

\section{ACKNOWLEDGMENTS}

The authors would like to thank the National Agricultural Innovation Program, the Technological Institute of Production, CITE agroindustrial - Ica for the allocation of the budget for the conduction of this research 


\section{REFERENCES}

1. UN Human Rights Council. Report of the Special Rapporteur on the right to food, Olivier De Schutter. United Nations. 2017.

2. Herrera - Estrella A, Chet I. Biocontrol of bacteria and phytopathogenic fungi. pp. 263 - 283. In: Agricultural Biotechnology. Altman A. (Edn). Marcel Dekker, Inc. New York, USA. 1998.

3. Bai Z, Jin B, Li Y, Chen J, Li, Z. Utilization of winery wastes for Trichoderma viride biocontrol agent production by solid state fermentation. Int J Environ Sci. 2008;20:353-358.

4. Calistru C, McLean M, Berjak P. In vitro studies on the potential for biological control of Aspergillus flavus and Fusarium moniliforme by Trichoderma species. A study of the production of extracellular metabolites by Trichoderma species. Mycopathologia. 1997; 137:115-124.

5. Calistru C, McLean M, Berjak P. In vitro studies on the potential for biological control of Aspergillus flavus and Fusarium moniliforme by Trichoderma species 1. Macroscopical and microscopical observations of fungal interactions. Mycopathologia. 1997;139:115-121.

6. Bankole SA, Adebanjo A. Biocontrol of brown blotch of cowpea caused by Colletotrichum truncatum with Trichoderma viride. Crop Prot. 1996; 15:633-636.

7. Fourie PH, Halleen F. Chemical and biological protection of grapevine propagation material from trunk disease pathogens. Eur J Plant Pathol. 2006;116:225-265.

8. Halleen F, Fourie PH, Lombard PJ. Protection of grapevine pruning wounds against Eutypa lata by biological and chemical methods. S Afr J Enol Vitic. 2010;31:125-132.

9. Mutawila C, Fourie PH, Halleen F, Mostert L. Grapevine cultivar variation to pruning wound protection by Trichoderma species against trunk pathogens. Phytopathol Mediterr. 2011;50:264-276.

10. Kotze C, Van Niekerk JM, Mostert L, Halleen F, Fourie PH. Evaluation of biocontrol agents for grapevine pruning wound protection against trunk pathogen infection. Phytopathol Mediterr. 2011;50: 247-263.

11. Plata-Caudillo JA. Aislamiento y evaluación in vitro del efecto de Trichoderma spp. nativas sobre hongos patógenos de la madera de vid aislados en la región vitivinícola de Ensenada, Baja California. (Tesis de Maestría, Centro de Investigación y de Educación Superior de Ensenada, Baja California). 2010.

12. Singh RP. (Edsn) Principles and Applications of Environmental Biotechnology for a Sustainable Future. Applied Environmental Science and Engineering for a Sustainable Future. Springer Science + Business Media Singapore. 2017;487.

13. Dela-Cruz-Quiroz R, Roussos S, Hernández D, Rodríguez R, Castillo F, Aguilar CN. Challenges and opportunities of the biopesticides production by solid-state fermentation: filamentous fungi as a model. Crit Rev Biotechnol. 2015;35:326-333.

14. Albores S, Julia M, Matilde P, Maria S, Cerdeiras P. Biodegradation of agro industrial wastes by Pleurotus spp for its use as ruminant feed. Electronic J Biotechnol. 2006;9:215-220.

15. Sanchez C. Lignocellulosic Residues: Biodegradation and Bioconversion by Fungi. Biotechnol Adv. 2009;27:185-194.

16. Hjeljord A, Tronsmo HL. (1998). Trichoderma and Gliocladium in biological control, and overview. Trichoderma and Gliocladium. 1998;2:131-145.

17. Fernández-Larrea VO. Tecnologías para la producción de biopesticidas a base de hongos entomopatógenos y su control de la calidad. Laboratorio de Hongos Entomopatógenos. Instituto de Investigaciones de Sanidad Vegetal (INISAV). La Habana Cuba. 2004;10.
18. Chaudhari PJ, Shrivastava P, Khadse AC. Substrate evaluation for mass cultivation of Trichoderma viride. Asiatic J Biotech Res. 2010;2:441-446.

19. Michel-Aceves AC, Otero-Sánchez MA, Martínez-Rojero RD, Ariza-Flores R, Barrios-Ayala A, Rebolledo-Martínez A. Control biológico in vitro de enfermedades fungosas en tomate Lycopersicum esculentum Mill. Avances en Investigación Agropecuaria. 2008;12:55-68.

20. Gómez RH, Soberanis RW, Tenorio CM, Torres SE. Manual de producción y uso de hongos antagonistas. In SENASA (Edn), Lima. Perú. 2013;40.

21. Pineda-Insuasti JA, Benavides-Sotelo EN, Duarte-Trujillo AS, Burgos-Rada CA, Soto-Arroyave CP, Pineda-Soto, CA, et al. Producción de biopreparados de Trichoderma spp: una revisión. ICIDCA. Sobre los Derivados de la Caña de Azúcar. 2017;51:47-52.

22. Velez PE, Posada FJ, Marin P, Gonzalez MT, Osorio E, Bustillo AE. Técnicas para el control de calidad de formulaciones de hongos entomopatógenos. In Cenicafe (Edn), (Primera edicion edn). Colombia: Ospina, H.F. 1997.

23. Cañedo V, Ames T. Manual de laboratorio para el manejo de hongos entomopatógenos. Centro Internacional de la Papa (CIP), PER. 2004.

24. Gómez H, Soberanis W, Tenorio M, Torres Del Águila E. Manual de producción y uso de hongos antagonistas. Senasa. 2013;1-34.

25. Moore-Landecker E. Fundamentals of the fungi (No. Edn. 4). Prentice Hall. New Jersey, USA. 1996;574.

26. Elósegui O. Métodos artesanales de producción de bioplaguicidas a partir de hongos entomopatógenos y antagonistas. La HabanaCuba: Instituto de Investigaciones de Sanidad Vegetal (INISAV). 2006;6-8.

27. Mwangi PW, Chemining'wa GN, Mburu MW, Mureithi JG. Decomposition and nutrient release rates of selected legume residues in a cold semiarid environment of Kenya. IJAAR. 2013;3:1-13.

28. Thompson LM, Troeh FR. Los suelos y su fertilidad. In J Puigdefábregas Tomás (Edn), Química del suelo (4 Edn). Barcelona, España: Reverté. 1988:308-309.

29. Tovar Castaño JC. Evaluación de la capacidad antagonista" in vivo" de aislamientos de Trichoderma spp frente al hongo fitopatogeno Rhizoctonia solani (Bachelor's thesis, Facultad de Ciencias). 2008.

30. Kobori NN, Mascarin GM, Jackson MA, Schisler DA. Liquid culture production of microsclerotia and submerged conidia by Trichoderma harzianum active against damping-off disease caused by Rhizoctonia solani. Fungal Biology. 2014;119:179-190.

31. Villamizar LF, Nelson TL, Jones SA, Jackson TA, Hurst MRH, Marsshall SDG. Formation of microesclerotia in three species of Beauveria and storage stability of a prototype granular formulation. Biocontrol Sci Technol. 2018;28:1097-1113.

32. Michel-Aceves AC, Otero-Sánchez MA, Martínez-Rojero RD, Rodríguez-Morán NL, Ariza-Flores R, Barrios-Ayala A. Producción masiva de Trichoderma harzianum Rifai en diferentes sustratos orgánicos. Revista Chapingo. Serie horticultura. 2008;14:185-191.

33. Brown C. Carbon: Nitrogen Ratios of Organic Amendments. 2015.

34. Gaind S, Nain L, Patel VB. Quality evaluation of co-composted wheat straw, poultry droppings and oil seed cakes. Biodegradation. 2009;20:307-317

35. Schuldt M. Manual de Lombricultura, relaciones carbono/ nitrógeno. 2006. 
36. Pérez-Guerra N, Torrado-Agrasar A, López-Macias C, Pastrana L. Main characteristics and applications of solid substrate fermentation. Elec J Env Agricult Food Chem. 2002;2:1-85.

37. Padmasari Y. Fungal Mats in Solid - State Fermentation. PhD Thesis, Wageningen University, Wageningen, The Netherlands. 2005.

38. McBeath J, Adelman M. Taxonomy of a new Trichoderma found in Alaska. Phytopathology. 1991;81:128.

39. Fonseca A. Estudio preliminar sobre la dinámica poblacional del bio-controlador Trichoderma spp. en el suelo. Tesis de pregrado. Bacteriología. Facultad de Ciencias. Pontificia Universidad javeriana, Bogotá-Colombia. 1998;29-32.

40. Wells H, Bell D, Jaworski C. Efficacy of Trichoderma harzianum as a biocontrol for Sclerotium rolfsii. Phytopathology. $1972 ; 62: 442-447$
41. Purschwitz J, Muller S, Kastner C, Fischer R. Seeing the rainbow: Light sensing in fungi. Current Opinion in Microbiology. 2006;95:66-71.

42. Martínez B, Infante D, Reyes Y. Trichoderma spp. y su función en el control de plagas en los cultivos. Revista de Protección Vegetal. 2013;28:1-11

43. Gómez Ramírez, H. Trichoderma viride Pers. Cepa CCB-LA103. 2014.

44. Indecopi. Resolución No 020525-2007/DSD-Otorgamiento de la denominación de origen Pallar de Ica. Instituto Nacional de Defensa de la Competencia y de la Propiedad Intelectual. 2007. 